\title{
EFEKTIVITAS MODEL PEMBELAJARAN DARING PADA SISWA BERKEBUTUHAN KHUSUS
}

\section{Anissa Rizky Andriany, Ajheng Mulamukti Asih Pratiwi, Mahesti Pertiwi}

Fakultas Psikologi, Universitas Muhammadiyah Prof. Dr. Hamka, Jakarta, Indonesia

Email: anissarizkyandriany@uhamka.ac.id, ajheng@uhamka.ac.id,

mahesti@uhamka.ac.id

\begin{abstract}
Abstrak
Pandemi Covid 19 telah membuat pemerintah Indonesia mengambil kebijakan untuk menerapkan pembelajaran secara daring untuk menggantikan pembelajaran tatap muka, tanpa terkecuali termasuk pada siswa berkebutuhan khusus. Kebijakan pembelajaran daring pada siswa berkebutuhan khusus tentu berdampak pada efektifitas pembelajaran. Penelitian ini bertujuan untuk melihat bagaimana efektivitas pembelajaran daring yang dilihat dari perspektif guru yang mengajar siswa berkebutuhan khusus. Penelitian ini menggunakan metode deskriptif kualitatif. Teknik pengumpulan data menggunakan instrumen google form dan wawancara melalui zoom meeting kepada 41 responden yang bersedia dihubungi secara langsung. Hasil penelitian menunjukkan bahwa pembelajaran daring yang sudah dilaksanakan kepada siswa berkebutuhan khusus belum cukup mampu untuk menggantikan pembelajaran tatap muka. Ketidaksiapan guru, siswa dan orangtua baik dari sisi kemampuan menggunakan teknologi, koneksi jaringan internet yang kurang stabil, kesiapan orangtua dalam mendampingi siswa dalam belajar, serta belum mampunya siswa berkebutuhan khusus untuk beradaptasi dengan metode pembelajaran yang baru menjadi faktor yang membuat pembelajaran daring belum efektif dilaksanakan.
\end{abstract}

Kata Kunci: pembelajaran daring; anak berkebutuhan khusus; covid-19

\section{Abstract}

The Covid 19 pandemic has led the Indonesian government to take a policy to implement online learning to replace face-to-face learning, without exception including students with special needs. Online learning policies in students with special needs certainly have an impact on the effectiveness of learning. The study aims to look at how the effectiveness of online learning is viewed from the perspective of teachers teaching students with special needs. This research uses qualitative descriptive methods. Data collection techniques using google form instruments and interviews through zoom meetings to 41 respondents who are willing to be contacted directly. The results showed that online learning that has been implemented for students with special needs has not been able to replace faceto-face learning. The unpreparedness of teachers, students, and parents both in terms of the ability to use technology, a less stable internet network connection, parental readiness in accompanying students in learning, and the inability of

$\begin{array}{ll}\text { How to cite: } & \text { Andriyany. A.R., Ajheng Mulamukti A Pratiwi \& Mahesti Pertiwi (2021) Efektivitas Model } \\ & \text { Pembelajaran Daring Pada Siswa Berkebutuhan Khusus. Syntax Literate: Jurnal Ilmiah Indonesia, } \\ & 6(10) . \text { http://dx.doi.org/10.36418/ Syntax-Literate.v6i10.4348 } \\ \text { E-ISSN: } & \text { 2548-1398 } \\ \text { Published by: } & \text { Ridwan Institute }\end{array}$

Published by: Ridwan Institute 
students with special needs to be adapted to new learning methods are factors that make online learning has not been effectively implemented.

Keywords: online learning; children with special needs; covid-19

Received: 2021-09-20; Accepted: 2021-10-05; Published: 2021-10-20

\section{Pendahuluan}

Pendidikan merupakan sebuah proses pengembangan diri yang dilakukan secara berkelanjutan semasa hidup dalam rangka meningkatkan kemampuan, pengetahuan, pemahaman atau keterampilan seseorang (Yuliani et al., 2020). Pendidikan juga merupakan perlindungan bagi anak karena pendidikan merupakan proses untuk menciptakan kondisi anak-anak agar dapat melaksanakan hak dan kewajibannya demi pertumbuhan dan perkembangannya yang wajar baik secara rohani, jasmani dan sosial (Gultom, 2014) sebagaimana yang telah dijelaskan dalam Undang-Undang Dasar 1945 pasal 31 ayat 1 yang menyatakan bahwa setiap warga negara memiliki hak untuk mendapatkan pendidikan yang bermutu yang diselenggarakan oleh Pemerintah Republik Indonesia. Proses pendidikan yang merupakan hak dan kewajiban seluruh anak bangsa harus dilaksanakan tanpa memandang seseorang dari segi apapun, seperti jenis kelamin, usia, maupun keadaan seseorang. Oleh karena itu, setiap warga negara berhak memperoleh proses pendidikan, termasuk di dalamnya Anak Berkebutuhan Khusus $(\mathrm{ABK})$.

Anak berkebutuhan khusus memerlukan layanan pendidikan yang sesuai dengan kebutuhan belajar masing-masing anak (Pradipta et al., 2020). Hal ini sejalan dengan undang-undang Pendidikan Individu dengan Disabilitas (Individuals with Disabilities Education Act - IDEA) mengamanatkan layanan untuk semua anak dengan disabilitas (Friend \& Yeo, 2011). Hal ini mencakup penetapan evaluasi dan kelayakan pendidikan, pendidikan yang tepat serta Individual Educational Plan (IEP), serta pendidikan di lingkungan yang terbatas (Smith, D. D., \& Tyler, 2010); (Taylor, R. L., Smiley, L., \& Richards, 2009).

Pendidikan khusus untuk anak-anak berkebutuhan khusus harus diberikan dengan sebaik-baiknya. Misalnya kelainan perilaku dan hambatan emosional yang bisa diketahui apabila ia tidak mampu belajar bukan disebabkan faktor intelektual, tidak mampu melakukan hubungan baik dengan teman dan guru, bertingkah laku dan berperasaan tidak pada tempatnya, mereka selalu dalam keadaan pervasive atau ketakutan dalam suatu hal (Takdir Ilahi, 2013), hal ini di lakukan dalam rangka meningkatkan pendidikan bagi anak berkebutuhan khusus, pendidik harus mengetahui sepenuhnya nilai pendidikan bagi anak berkebutuhan khusus, keadaan dan karakteristik (kelebihan dan kekurangan) anak berkebutuhan khusus, serta penanganannya di kelas yang dapat dilakukan guru untuk memaksimalkan kemampuan yang dimiliki oleh anak berkebutuhan khusus (Lisinus \& Sembiring, 2020).

Pandemi Covid-19 yang melanda Indonesia sejak awal Maret 2020 hingga saat ini telah membuat 1.410.134 jiwa terkonfirmasi positif (Hafni, 2021). Pandemi Covid- 
19 yang terjadi di Indonesia turut berdampak pada kehidupan masyarakat Indonesia. Rumitnya penanganan wabah ini membuat pemerintah menerapkan kebijakan yang sangat ketat untuk memutus mata rantai penyebaran Covid-19, salah satunya adalah social distancing. Kebijakan social distancing, yang dituangkan dalam Peraturan Pemerintah Nomor 21 Tahun 2020 tentang kebijakan PSBB (Pembatasan Sosial Berskala Besar). Penerapan kebijakan tersebut menimbulkan keresahan bagi masyarakat dan cukup memberikan dampak yang besar pada perekonomian hingga pendidikan. Selain itu, berbagai kebijakan diterapkan untuk mengadaptasi segala perubahan yang terjadi secara tiba-tiba, sehingga tidak ada penurunan kinerja dalam berbagai bidang.

Pembelajaran jarak jauh menjadi alternatif terbaik yang dapat dilakukan agar pembelajaran dapat berlangsung walaupun siswa berada di rumah. Pembelajaran daring adalah pembelajaran yang dilakukan dengan menggunakan jaringan internet sebagai tempat menyalurkan ilmu pengetahuan (Syarifudin, 2020). Pembelajaran daring atau jarak jauh sendiri diyakini dapat membuat siswa memiliki waktu yang banyak untuk belajar, dan siswa dapat belajar kapanpun dan dimanapun. Ketersediaan aplikasi atau media, seperti google classroom, video conference, telepon atau live chat, zoom meeting, atau grup whatsapp, memudahkan guru untuk berinteraksi dengan siswa pada situasi pandemi seperti ini. Namun, tidak semua sekolah berhasil melaksanakan sistem belajar daring sesuai dengan hasil yang diharapkan, terutama pada sekolah yang menampung anak berkebutuhan khusus di dalamnya.

Pembelajaran secara daring tidak hanya diterapkan pada peserta didik yang typical (normal), melainkan juga dilakukan pada peserta didik atypical (berkebutuhan khusus), baik secara fisik, mental-intelektual, sosial maupun emosional. Pembelajaran daring bagi siswa berkebutuhan khusus akan mengalami banyak hambatan apabila tidak ada kerjasama mulai dari orang tua dalam mendampingi pembelajaran di rumah dengan guru yang mengajar secara daring (Hamidaturrohmah, H., \& Mulyani, 2020). Kesiapan lembaga pendidikan untuk melaksanakan pembelajaran daring turut menjadi masalah tersendiri. Ketersediaan perangkat teknologi yang dimiliki oleh masing-masing lembaga pendidikan untuk menunjang proses pembelajaran, kemampuan pendidik maupun peserta didik menggunakan teknologi, keterbatasan perangkat teknologi yang dimiliki oleh masing-masing peserta didik, akses internet yang belum stabil di tempat tinggal peserta didik maupun pendidik, maupun kendala biaya karena metode pembelajaran dilakukan secara daring tentunya akan berpengaruh pada kualitas pembelajaran daring, terkhusus pada lembaga pendidikan yang menampung peserta didik berkebutuhan khusus, seperti sekolah inklusi dan sekolah luar biasa.

Pelaksanaan pembelajaran secara daring pada masa pandemi covid-19 menghadirkan permasalahan tersendiri bagi guru, orang tua, dan terutama bagi anak berkebutuhan khusus. Anak berkebutuhan khusus sulit melaksanakan pembelajaran secara online (Minsih, Nandang, \& Kurniawan, 2021). Pesatnya perkembangan teknologi serta penggunaan media sosial dan aplikasi yang digunakan sebagai media pembelajaran daring turut menjadi faktor terhambatnya efektivitas pengajaran daring bagi siswa berkebutuhan khusus. Adanya pandemi Covid-19 yang mengharuskan 
lembaga pendidikan meninggalkan pembelajaran konvensional secara tatap muka dan mengganti dengan metode pembelajaran daring secara penuh, maka terbuka ruang untuk meneliti bagaimana efektivitas pembelajaran daring yang dilaksanakan.

Sejauh ini telah ada beberapa penelitian yang dilakukan untuk melihat bagaimana proses pembelajaran daring pada siswa berkebutuhan khusus yang dilakukan di masa pandemi Covid-19. Penelitian (Syafarana \& Chairani, 2020) menyimpulkan bahwa pembelajaran daring tidak semudah pembelajaran di sekolah yang melakukan tatap muka. Banyak sekali tantangan yang guru hadapi seperti anak yang tidak memiliki keinginan untuk melakukan pembelajaran dan kurangnya konsentrasi anak berkebutuhan khusus saat melakukan pembelajaran online. Di sisi lainnya, penelitian (Jannah, Wulandari, \& Budi, 2020) menjelaskan bahwa pembelajaran daring membuat anak berkebutuhan khusus mendapat pengalaman baru dalam mengoperasikan telepon seluler sebagai sarana belajar seperti anak lainya, yang dapat menumbuhkan kepercayaan diri mereka. Terkait dengan efektivitas pembelajaran online pada anak berkebutuhan khusus belum banyak yang meneliti. Akan tetapi, ditemukan penelitian terkait efektivitas pembelajaran daring pada peserta didik typical. Berdasarkan penelitian yang dilakukan oleh (Hikmat, Hermawan, Aldim, \& Irwandi, 2020) diketahui bahwa pembelajaran daring hanya efektif untuk matakuliah teori dan praktikum saja, sementara untuk matakuliah praktikum dan matakuliah lapangan tidak efektif dilakukan secara daring.

Beberapa penelitian di atas menjadi kajian yang menarik sebagai literatur sebelumnya yang memiliki perbedaan aspek dengan penelitian yang dilakukan ini. Penelitian ini lebih berfokus pada bagaimana efektivitas pembelajaran daring (online) selama pandemi Covid-19 berlangsung. Pentingnya penelitian ini karena memiliki tujuan yang spesifik untuk mendeskripsikan bagaimana efektivitas pembelajaran daring dari persepsi pengajar selama pandemi agar dapat dirumuskan langkah lanjutan yang dapat mengatasi permasalahan proses pembelajaran pada siswa berkebutuhan khusus.

\section{Metode Penelitian}

Penelitian ini menggunakan metode penelitian kualitatif deskriptif. Penelitian kualitatif deskriptif adalah sebuah penelitian yang menggunakan metode atau pendekatan studi kasus (Creswell \& Creswell, 2017). Penelitian deskriptif merupakan suatu bentuk penelitian yang ditujukan untuk mendeskripsikan fenomena-fenomena yang ada, baik fenomena alamiah maupun fenomena buatan manusia. Fenomena itu bisa berupa bentuk, aktivitas, karakteristik, perubahan, hubungan, kesamaan, dan perbedaan antara fenomena yang satu dengan fenomena lainnya (Sukmadinata, 2006). Jenis penelitian yang termasuk dalam kategori deskriptif adalah studi kasus dan penelitian survei.

Penelitian ini merupakan penelitian survei dengan subjek penelitian adalah guru anak berkebutuhan khusus. Data diperoleh dari guru-guru ABK yang bersedia dimintai keterangannya terkait pengalaman mengajar selama pandemi berlangsung. Dengan kata lain, data dalam penelitian ini dikumpulkan dari berbagai sumber. 
Metode dalam penelitian terdiri dari kuantitatif dan data kualitatif berdasarkan jenis pertanyaan yang diberikan, yaitu pertanyaan terbuka dan tertutup. Metode kuantitatif digunakan saat menghitung jumlah pilihan jawaban responden dengan cara tabulasi data dan presentase jawaban yang masuk. Metode kualitatif digunakan untuk menganalisa jawaban dari pertanyaan terbuka yang diberikan.

Penelitian ini dilakukan pada bulan April - Mei 2021, melalui google form dan aplikasi zoom meeting ataupun Whatsapp. Google form digunakan oleh peneliti untuk menghimpun data kuesioner serta ketersediaan guru-guru ABK dihubungi secara langsung oleh peneliti. Google Form atau Google Formulir adalah fitur di Google yang bertujuan untuk memudahkan membuat survei melalui internet (Sudaryo, Sofiati, Medidjati \& Hadiana, 2019). Sementara, zoom meeting dan whatsapp digunakan oleh peneliti untuk mewawancarai guru abk yang telah mengisi google form sebelumnya serta menghindari resiko menyebarnya virus corona kepada pihak-pihak terkait.

Penelitian ini melibatkan 41 orang guru ABK yang berasal dari SLB, Sekolah Inklusi, ataupun Lembaga Terapi yang menjalani proses Pembelajaran Jarak Jauh (PJJ) di masa pandemi Covid-19. Teknik pengambilan sampel dalam penelitian ini adalah random sampling. Sampel dalam penelitian ini dipilih secara random sampling dengan kriteria sebagai guru anak berkebutuhan khusus.

Aspek survei yang diberikan pada guru ABK dikaitkan dengan pelaksanaan PJJ. Kisi-kisi survei guru, yakni profil/latar belakang guru, adanya PJJ selama pandemi dan sosialisasi PJJ dari sekolah (jadwal, waktu, durasi pelaksanaan PJJ), tujuan pembelajaran, media komunikasi yang digunakan, sarana prasana pembelajaran, metode pembelajaran, materi dan pelaksanaan pembelajaran dalam PJJ, kemampuan guru dan siswa ABK dalam menggunakan teknologi, efisiensi waktu, kendala selama PJJ, serta saran dan harapan guru. Pertanyaan untuk responden guru ABK berjumlah 28 pertanyaan, terdiri dari 22 pertanyaan tertutup atau kategorial dan sisanya merupakan pertanyaan terbuka. Analisa data dilakukan secara kuantitatif dan kualitatif bergantung pertanyaan yang diajukan. Analisa kuantitatif berdasarkan data persentase yang didapatkan. Sedangkan analisa kualitatif dilakukan berdasarkan jawaban responden.

\section{Hasil dan Pembahasan}

\section{A. Profil Responden}

Berdasarkan data yang masuk pada bulan April - Mei 2021, jumlah responden yang mengisi kuesioner sebanyak 41 orang. Sebanyak 36 orang $(87,8 \%)$ berjenis kelamin perempuan dan 5 orang $(12,2 \%)$ berjenis kelamin laki-laki. Beberapa informasi terkait usia, latar belakang pendidikan, jenjang ajar, jumlah siswa yang diajar, dan masa kerja dapat dilihat pada tabel 1. 
Tabel 1

Profil Responden

\begin{tabular}{|c|c|c|}
\hline & Frekuensi & Persentase $(\%)$ \\
\hline \multicolumn{3}{|l|}{ Usia (dalam tahun) } \\
\hline $20-29$ & 23 & $56,1 \%$ \\
\hline $30-39$ & 6 & $24,4 \%$ \\
\hline $40-49$ & 10 & $14,6 \%$ \\
\hline $50-59$ & 2 & $4,9 \%$ \\
\hline \multicolumn{3}{|l|}{$\begin{array}{l}\text { Jenjang Pendidikan } \\
\text { Terakhir }\end{array}$} \\
\hline D3 & 1 & $2,4 \%$ \\
\hline $\mathrm{S} 1$ & 34 & $82,9 \%$ \\
\hline $\mathrm{S} 2$ & 5 & $12,2 \%$ \\
\hline S3 & 1 & $2,4 \%$ \\
\hline \multicolumn{3}{|l|}{$\begin{array}{l}\text { Juruan Pendidikan } \\
\text { Terakhir }\end{array}$} \\
\hline Pendidikan Luar Biasa (PLB) & 19 & $46,3 \%$ \\
\hline Psikologi & 15 & $36,6 \%$ \\
\hline Pendidikan Luar Sekolah & 2 & $4,9 \%$ \\
\hline (PLS) & 1 & $2,4 \%$ \\
\hline Terapi & 1 & $2,4 \%$ \\
\hline $\begin{array}{l}\text { Pendidikan Bahasa Inggris } \\
\text { Lainnya }\end{array}$ & 3 & $7,3 \%$ \\
\hline \multicolumn{3}{|l|}{ Jenjang Ajar } \\
\hline SD & 30 & $73,2 \%$ \\
\hline SMP & 4 & $9,8 \%$ \\
\hline SMA & 2 & $4,9 \%$ \\
\hline Lainnya & 5 & $12,2 \%$ \\
\hline \multicolumn{3}{|l|}{ Jumlah Siswa yang diajar } \\
\hline$<4$ orang & 18 & $43,9 \%$ \\
\hline $4-6$ orang & 16 & $39 \%$ \\
\hline $7-9$ orang & 2 & $4,9 \%$ \\
\hline$>10$ orang & 5 & $12,2 \%$ \\
\hline \multicolumn{3}{|l|}{ Masa Kerja } \\
\hline$<3$ tahun & 21 & $51,2 \%$ \\
\hline $3-5$ tahun & 3 & $7,3 \%$ \\
\hline$>5$ tahun & 17 & $41,5 \%$ \\
\hline
\end{tabular}

Berdasarkan tabel 1, terlihat bahwa responden memiliki latar belakang dan kondisi yang beragam. Sebagian besar responden berada di usia 20 - 29 tahun, berlatar belakang Pendidikan S1 dengan jurusan Pendidikan Luar Biasa (PLB) dan masa kerja di bawah 3 tahun. Jenjang pendidikan yang diajar responden sebagian besar berada pada tingkat Sekolah Dasar (SD), dengan jumlah siswa kurang dari 4 siswa dalam 1 kelas. Selanjutnya, data mengenai gambaran kondisi siswa dan proses belajar mengajar selama pandemi dapat dilihat pada tabel 2 . 
Tabel 2

Kondisi siswa dan proses belajar mengajar selama pandemi

\begin{tabular}{lcc}
\hline & Frekuensi & Persentase (\%) \\
\hline Kategori Siswa & 5 & $12,2 \%$ \\
\hline Tuna Rungu & 1 & $2,4 \%$ \\
Tuna Wicara & 4 & $9,8 \%$ \\
Tuna Grahita & 5 & $12,2 \%$ \\
Kesulitan Belajar & 5 & $12,2 \%$ \\
Lambat Belajar & 16 & $39 \%$ \\
Autisme & 5 & $12,2 \%$ \\
Lainnya & & \\
\hline Jumlah Pertemuan / & & \\
Minggu & 7 & $17,1 \%$ \\
\hline 1 kali & 5 & $12,2 \%$ \\
2 kali & 17 & $01,5 \%$ \\
3 kali & 0 & $29,3 \%$ \\
4 kali & 12 & $17,1 \%$ \\
5 kali & & $17,1 \%$ \\
\hline Durasi KBM / pertemuan & 7 & $24,4 \%$ \\
\hline 30 menit & 7 & $31,7 \%$ \\
60 menit & 10 & $9,8 \%$ \\
90 menit & 13 & $48,8 \%$ \\
120 menit & 4 & \\
150 menit & & \\
\hline Aplikasi yang digunakan & 20 & \\
\hline Aplikasi berbasis video & & \\
conference (zoom meeting, & & \\
google meeting, dsb) & 10 & \\
Aplikasi berbasis non video & & \\
conference (whatsapp group, & & \\
chat whatsapp, youtube, dsb) & & \\
Gabungan aplikasi berbasis & & \\
video conference dan non & & \\
video conference & & \\
\hline
\end{tabular}

Data pada tabel 2 menunjukkan bahwa 39\% responden mengajar siswa dengan masalah autisme. Sebanyak 41,5\% responden mengajar sebanyak 3 kali seminggu dengan durasi 120 menit per pertemuan (31,7\% responden). Sebanyak 48,8\% responden mengajar dengan menggunakan aplikasi berbasis video conference berupa zoom meeting, google meeting, video call, dsb.

B. Hasil Survei Proses Pembelajaran Jarak Jauh pada Guru Anak Berkebutuhan Khusus

a. Ketercapaian tujuan Pembelajaran

Pembelajaran diartikan sebagai sebuah upaya yang sistematis dan sengaja untuk menciptakan interaksi edukatif antara dua pihak, yaitu peserta didik dan pendidik yang melakukan kegiatan pembelajaran. 
Pembelajaran daring dikatakan efektif apabila tujuan dari pembelajaran dapat tercapai, baik secara pertemuan tatap muka ataupun daring. Hasil pengisian kuesioner yang diisi oleh responden dapat dilihat dari grafik 1 berikut:

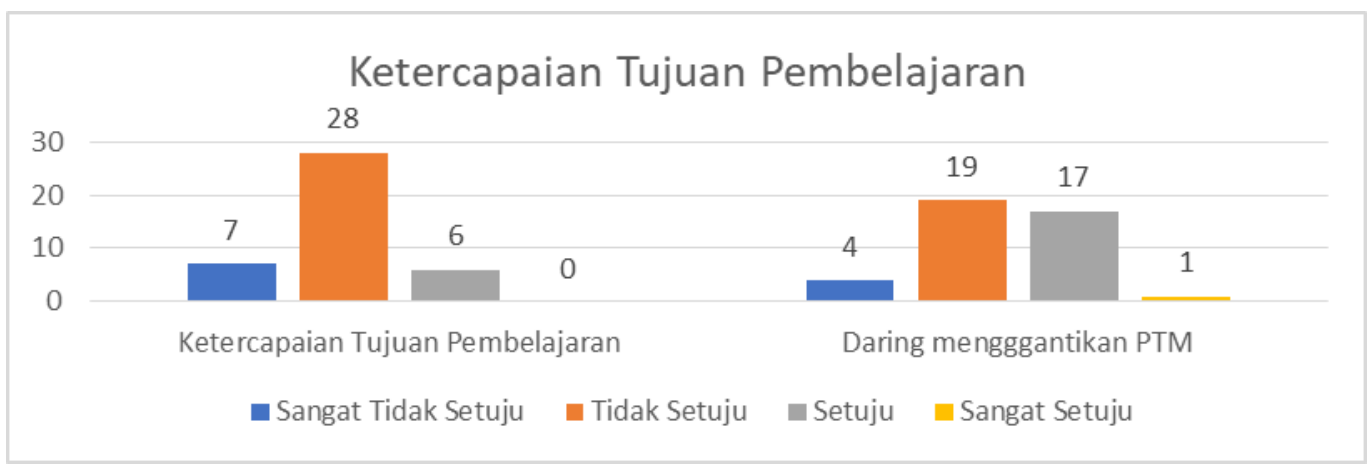

\section{Grafik 1 \\ Ketercapaian Tujuan Pembelajaran}

Dari Grafik 1 dapat dilihat sebanyak 28 responden merasa bahwa selama daring, tujuan pembelajaran tidak dapat tercapai. Sebanyak 19 responden merasa bahwa proses pembelajaran daring tidak dapat menggantikan pertemuan tatap muka dalam kondisi pandemi Covid-19.

Berdasarkan hasil wawancara yang dilakukan kepada responden, diketahui bahwa saat ini pembelajaran daring adalah satu-satunya pilihan yang dapat menggantikan pertemuan tatap muka agar proses pembelajaran pada masa Pandemi Covid-19 tetap berlangsung. Ketercapaian tujuan pembelajaran akan lebih mudah tercapai apabila ada kerja sama dari orang tua.

b. Sarana dan Prasarana

Pada pelaksanaan pembelajaran daring, guru dan murid sangat bergantung pada perangkat teknologi informasi baik berupa komputer/laptop/telepon selular yang terhubung pada jaringan internet (Pakpahan \& Fitriani, 2020). Sarana pembelajaran sangat berpengaruh terhadap kelancaran proses pembelajaran daring. Selama pembelajaran meliputi: akses internet di tempat tinggal yang berpengaruh terhadap koneksi internet selama pembelajaran daring, fasilitas pertemuan daring yang disediakan sekolah, dan ketersediaan perangkat yang memadai yang dimiliki oleh siswa. Apabila sarana ini tidak terpenuhi, maka proses pembelajaran daring tidak akan maksimal. Pertemuan daring yang dilakukan pada masa pandemi ini, secara otomatis sangat mengandalkan jaringan internet yang stabil. Keterbatasan akses internet tentu menjadi kendala saat pembelajaran daring berlangsung, karena dalam pembelajaran daring tidak hanya membutuhkan kualitas suara yang jernih, tetapi juga kualitas video yang stabil agar dapat membantu siswa dalam memahami materi yang diberikan. Hasil pengisian kuesioner oleh responden terkait sarana dan prasarana belajar daring dapat dilihat pada grafik 2 berikut: 


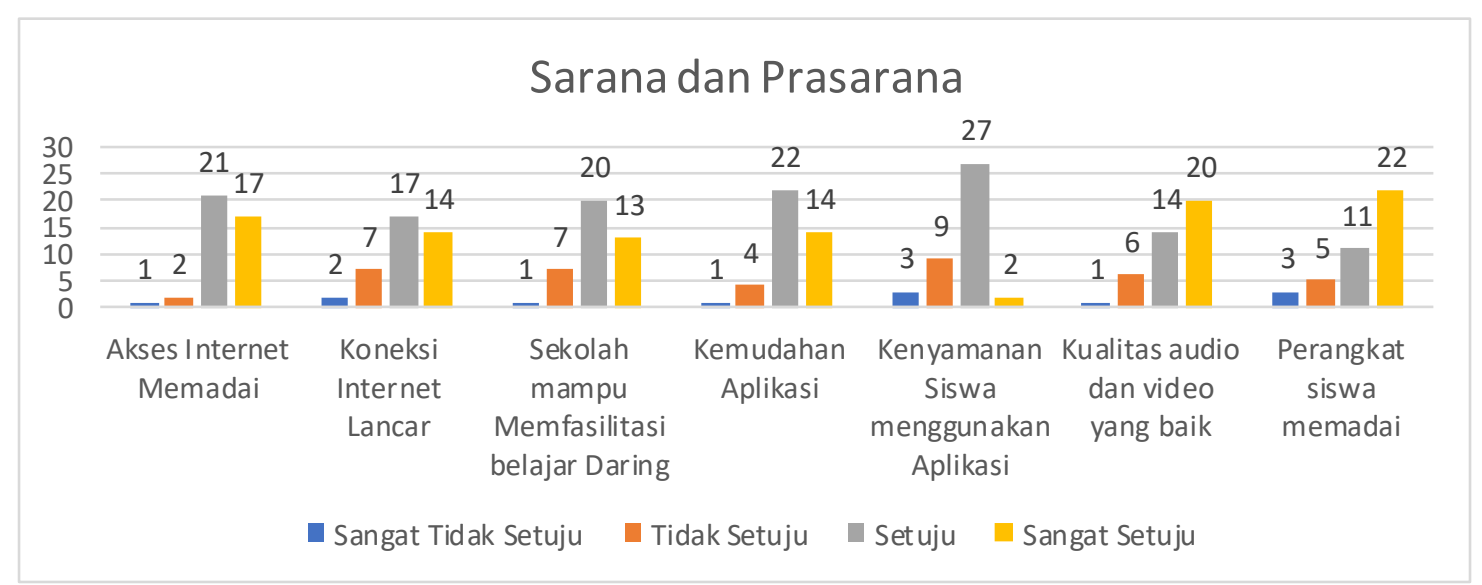

\section{Grafik 2 \\ Sarana dan Prasarana}

Dari grafik 2 dapat dilihat bahwa sebagian besar responden tidak memiliki kendala dalam aspek sarana dan prasarana. Hal ini dibuktikan oleh 38 responden menyatakan bahwa memiliki akses internet yang memadai. Tampak pula bahwa kualitas jaringan internet di tempat tinggal masing-masing responden cukup baik. Meskipun demikian, berdasarkan hasil wawancara ditemukan keluhan dari beberapa responden yang merasa siswa mereka memiliki kendala internet selama pembelajaran daring, sehingga mempengaruhi kelangsungan proses belajar mengajar. Dalam pembelajaran daring di masa pandemi Covid-19 diperlukan akses internet yang stabil agar proses pembelajaran berjalan dengan lancar.

Dalam hal penyediaan fasilitas pertemuan daring, responden merasa bahwa masing-masing tempatnya bekerja telah mampu menyediakan fasilitas pembelajaran daring. Sebanyak 33 orang mengatakan bahwa sekolah telah mampu mempersiapkan fasilitas pertemuan daring dengan baik. Berdasarkan hasil wawancara kepada beberapa responden, diketahui bahwa sekolah mereka telah memfasilitasi pertemuan daring dengan menyediakan pelatihan penggunaan aplikasi yang digunakan seperti google classroom, zoom meeting, google meeting, ataupun pembuatan media ajar yang interaktif pada awal pandemi.

Sejalan dengan hal tersebut, sebanyak 36 responden merasa bahwa aplikasi yang digunakan selama pembelajaran daring mudah digunakan dan dapat membantu pendidik untuk menyampaikan materi pembelajaran kepada masingmasing anak berkebutuhan khusus yang diajar. Kemudahan aplikasi tersebut tidak hanya dirasakan oleh responden sebagai pendidik. Sebanyak 29 responden merasa bahwa peserta didik yang diajar merasa nyaman untuk menggunakan aplikasi belajarnya. Hal ini menandakan bahwa saat ini peserta didik sudah mulai mampu beradaptasi dengan metode pembelajaran daring yang dilakukan 
secara mendadak di awal pandemi, meskipun masih diperlukan pendampingan dari orang tua agar siswa tetap dapat fokus saat proses belajar berlangsung.

Dalam ketersediaan perangkat pembelajaran yang dimiliki oleh peserta didik untuk melaksanakan pembelajaan daring, sebanyak 33 responden mengakui bahwa peserta didik memiliki perangkat yang memadai. Ketersediaan perangkat belajar, aplikasi yang mudah diakses serta kelancaran koneksi internet yang dimiliki oleh responden dan siswa, turut membuat kualitas audio dan video menjadi lebih jernih sehingga mampu mendukung proses pembelajaran selama pandemi Covid-19.

c. Kemampuan Guru dan Siswa Menggunakan Teknologi

Kemampuan guru dan siswa dalam menggunakan teknologi informasi dan komunikasi dalam pembelajaran daring akan berpengaruh pada capaian tujuan pembelajaran. Kesiapan guru ataupun siswa dalam menggunakan platform pembelajaran daring menjadi salah satu faktor pendukung efektivitas pembelajaran daring saat pandemi Covid-19. Kemampuan guru untuk menyiapkan materi pembelajaran yang menarik dan berbasis teknologi turut menjadi faktor penting bagi keberhasilan pembelajaran daring. Hasil pengisian kuesioner diperoleh data terkait kemampuan guru dan siswa mengunakan teknologi dapat dilihat pada grafik 3 berikut:

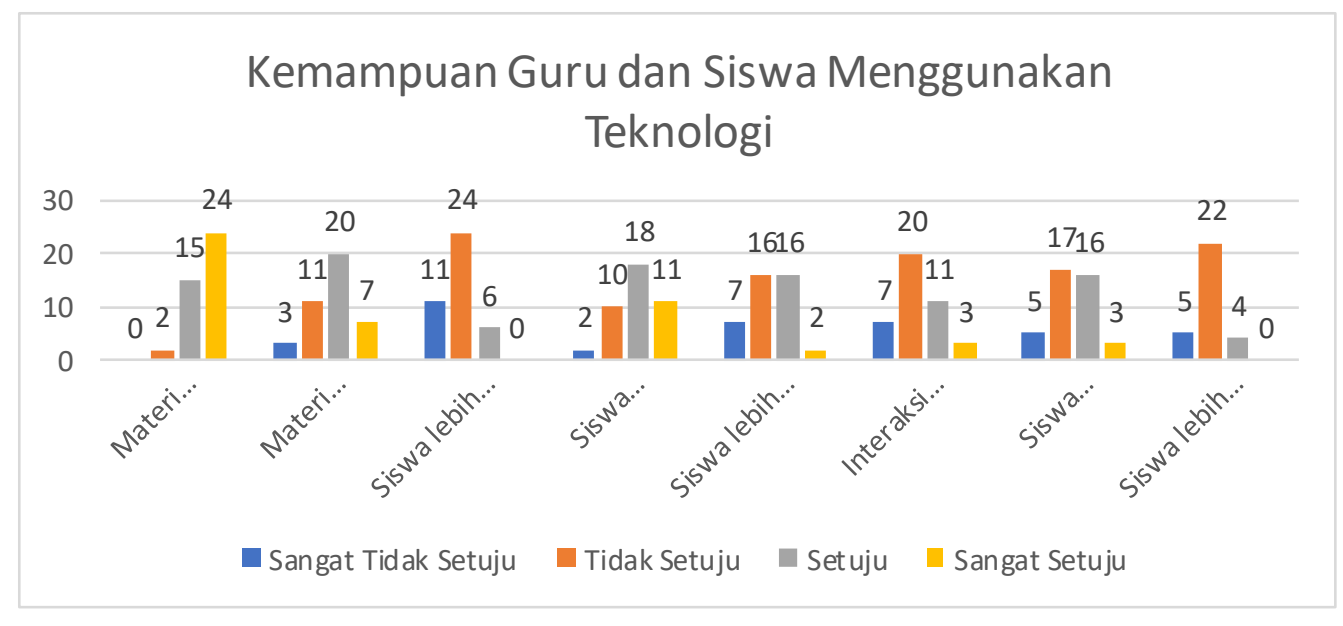

\section{Grafik 3}

Kemampuan Guru dan Siswa Menggunakan Teknologi

Dari grafik 3 terlihat bahwa sebanyak 39 responden telah mampu menyiapkan materi pembelajaran dengan sebaik-baiknya. 27 responden mengungkapkan bahwa materi yang telah mereka siapkan sudah tersampaikan dengan baik kepada siswa dan 29 responden mengungkapkan bahwa selama pembelajaran daring siswa lebih memiliki kesempatan untuk bertanya.

Meskipun demikian, jika melihat data pada grafik 3, diketahui bahwa sebanyak 35 responden masih menganggap siswa yang diajar masih mengalami kesulitan dalam memahami materi selama proses pembelajaran jarak jauh. 
Selain itu, sebanyak 23 responden merasa kesulitan untuk berkomunikasi dengan siswanya secara daring dibandingkan dengan pertemuan tatap muka langsung. Jika melihat data terkait interaksi antara guru dengan siswa, sebanyak 27 responden mengatakan hal ini menjadi kendala selama pembelajaran daring. Artinya, kemampuan dalam menggunakan media pembelajaran, baik dari guru maupun siswa masih belum baik dan ini menjadi hambatan dalam proses pembelajaran daring. Sebanyak 27 responden turut mengungkapkan bahwa mereka merasa para siswa mengalami kesulitan untuk menyampaikan hasil pekerjaan ataupun tuags secara daring dibandingkan saat pembelajaran tatap muka.

Hal ini sejalan dengan hasil wawancara yang dilakukan kepada sejumlah responden bahwa guru mengalami kesulitan untuk melakukan interaksi melalui video call secara langsung diwaktu yang bersamaan dengan pemberian materi. Responden juga mengungkapkan bahwa para siswa masih belum mampu untuk mengoperasikan aplikasi yang digunakan tanpa pendampingan orangtua, sehingga proses pembelajaran masing sangat bergantung pada ketersediaan waktu orang tua. Selain itu, berdasarkan hasil wawancara diketahui pula terdapat keluhan dari responden bahwa tugas-tugas yang diberikan selama pembelajaran daring seringkali telambat dikumpulkan karena siswa menunggu orang tua ataupun pendamping untuk dapat mengumpulkan tugas secara daring. Nampak bahwa kemampuan siswa bekebutuhan khusus dalam menggunakan tekonologi masih terbatas, sehingga menjadi hambatan dalam pembelajaran daring

d. Efisiensi Waktu

Pengelolaan alokasi waktu maupun jadwal pembelajaran daring harus diperhitungkan sebaik-baiknya penyelenggara pendidikan dalam hal ini adalah guru. Jumlah jam pertemuan yang selama ini dilakukan secara tatap muka harus mampu digantikan dengan pembelajaran daring. Pengalokasian waktu dan penjadwalan yang baik akan membuat tujuan pembelajaran tercapai. Pembelajaran daring seharusnya membuat waktu para siswa lebih efisien dibandingkan dengan pembelajaran tatap muka. Hasil pengisian kuesioner terkait efisiensi waktu dalam proses pembelajaran daring dapat dilihat pada grafik berikut: 


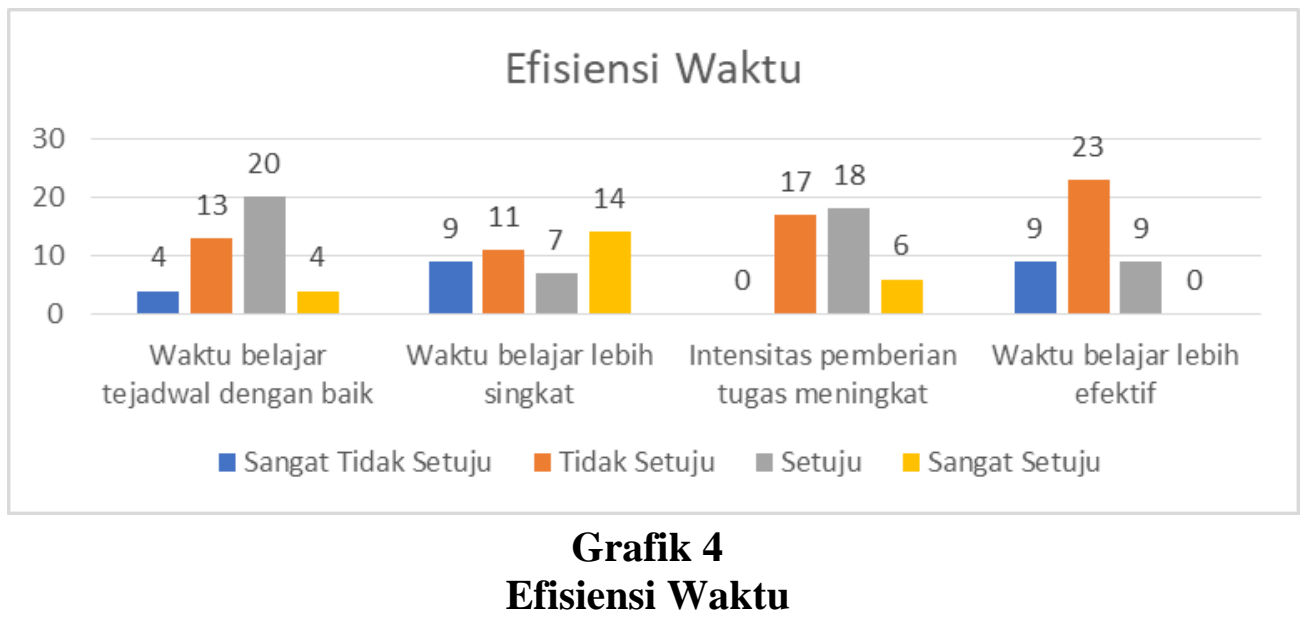

Berdasarkan data pada grafik 4 dapat diketahui bahwa sebanyak 23 responden merasa bahwa waktu pertemuan daring lebih singkat daripada pertemuan tatap muka. Sementara itu, sebanyak 24 responden mengungkapkan sekalipun pembelajaran dilakukan secara daring, mereka tetap menjadwalkan waktu belajar dengan rutin. Meskipun demikian, sekalipun pembelajaran dilakukan secara terjadwal, sebanyak 32 responden mengatakan bahwa pembelajaran daring tidak lebih efektif jika dibandingkan dengan tatap muka.

Berdasarkkan hasil wawancara, diketahui bahwa terdapat beberapa hal yang membuat responden merasa pembelajaran daring tidak lebih efektif jika dibandingkn dengan tatap muka antara lain: (1) kondisi siswa yang bervariasi dalam satu kelas, (2) jumlah siswa yang diajar, (3) emosi / mood siswa yang cenderung berubah-ubah dan tidak dapat terprediksi, (4) kestabilan koneksi internet yang dimiliki oleh siswa, serta (5) komitmen dari orang tua untuk dapat bekerja sama dengan baik dalam mendampingi proses belajar siswa berkebutuhan khusus.

e. Pembelajaran Daring di Masa Mendatang

Dengan kondisi pandemi yang belum jelas kapan berakhir, membuat dunia pendidikan di Indonesia harus berinovasi agar proses pembelajaran tetap dapat berlangsung demi kemajuan bangsa dan negara. Salah satu bentuk inovasi yang dapat dilakuakan adalah memberlakukan pembelajaran daring dalam proses pendidikan, meskipun kesiapan baik dari sisi sarana dan prasarana ataupun sumberdaya manusia dalam pembelajaran daring masing menjadi suatu hambatan yang besar bagi lembaga pendidikan. Hasil pengisian kuesioner yang telah dilakukan terkait kemungkinan pembelajaran daring di masa mendatang dapat dilihat dalam grafik berikut: 


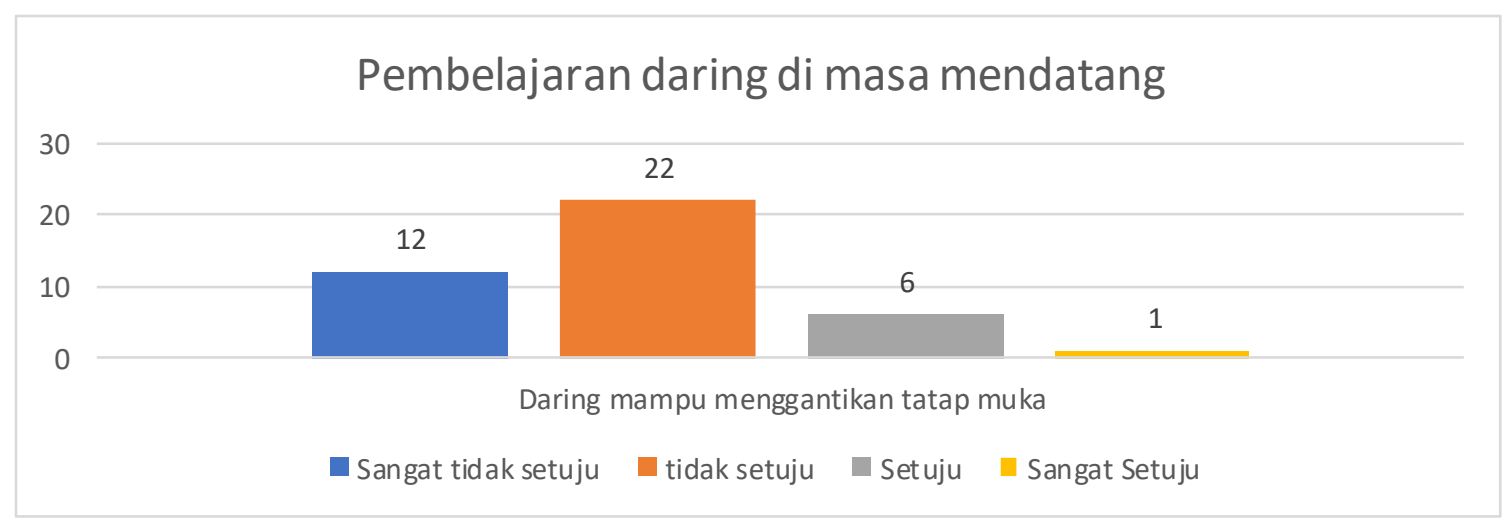

\section{Grafik 5}

Pembelajaran daring di masa mendatang

Dari grafik 5 dapat diketahui bahwa sebanyak 34 responden mengungkapkan bahwa pembelajaran daring tidak mampu menggantikan tatap muka. Hal ini sejalan dengan hasil wawancara yang mengungkap bahwa pembelajaran daring berpotensi pada turunnya kemampuan kognitif, perilaku dan juga sikap belajar dari setiap siswa berkebutuhan khusus. Selain itu, dari hasil wawancara juga terungkap bahwa dalam pembelajaran daring masih ditemukan kesulitan dalam proses mengelola kelas oleh para guru. Akibatnya, masih banyak siswa yang belum dapat mencapai target pembelajaran, mengalami penurunan hasil belajar, dan kecenderungan dari siswa untuk mengabaikan aturan-aturan belajar yang disebabkan kurangnya kerjasama antara guru dan juga orang tua.

\section{Kesimpulan}

Berdasarkan hasil penelitian, dapat disimpulkan bahwa proses pembelajaran jarak jauh yang sudah hampir 2 tahun dilaksanakan masih tetap menjadi satu-satunya pilihan yang harus diambil oleh Lembaga Pendidikan untuk memastikan proses pembelajaran tetap berlangsung. Berdasarkan hasil penelitian, ditemukan bahwa ada beberapa hal yang perlu disiapkan agar pembelajaran daring menjadi lebih efektif, antara lain: (1) kesiapan orang tua dalam mendampingi siswa berkebutuhan khusus dalam proses belajar, (2) kesiapan siswa untuk dapat belajar secara daring, (3) kesiapan sumber daya manusia yang dimiliki setiap lembaga pendidikan untuk menjalani pembelajaran daring, (4) ketersediaan aplikasi yang ramah pada anak berkebutuhan khusus, sehinga memudahkan siswa berkebutuhan khusus dalam proses belajar, (5) modifikasi kurikulum, sistem penugasan yang terstruktur dan mudah dilaksanakan oleh orang tua, serta (5) kemampuan guru dalam memanajemen kelas saat pembelajaran daring agar interaksi dan komunikasi antara guru dan siswa tetap terjalin dengan baik sekalipun pembelajaran dilakukan secara daring. 


\section{BIBLIOGRAFI}

Creswell, John W., \& Creswell, J. David. (2017). Research Design: Qualitative, Quantitative, And Mixed Methods Approaches. New York: Sage Publications. Google Scholar

Friend, James, \& Yeo, Leslie Y. (2011). Microscale Acoustofluidics: Microfluidics Driven Via Acoustics And Ultrasonics. Reviews Of Modern Physics, 83(2), 647. Google Scholar

Gultom, Maidin. (2014). Perlindungan Hukum Terhadap Anak Dalam Sistem Peradilan Pidana Anak Di Indonesia. Bandung: Refika Aditama. Google Scholar

Hafni, Roswita. (2021). Dampak Pandemi Covid-19 Terhadap Pendidikan Online. Seminar Nasional Teknologi Edukasi Sosial Dan Humaniora, 1(1), 601-611. Google Scholar

Hamidaturrohmah, H., \& Mulyani, T. (2020). Strategi Pembelajaran Jarak Jauh Siswa Berkebutuhan Khusus Di Sd Inklusi Era Pandemi Covid-19. Elementary: Islamic Teacher Journal, 8(2). 247-278. Google Scholar

Hikmat, Hikmat, Hermawan, Endang, Aldim, Aldim, \& Irwandi, Irwandi. (2020). Efektivitas Pembelajaran Daring Selama Masa Pandemi Covid-19: Sebuah Survey Online. $L p 2 m$. Google Scholar

Jannah, Rehan Nil, Wulandari, Nurul Lathifa, \& Budi, Setia. (2020). Pengalaman Belajar Daring Siswa Berkebutuhan Khusus Pada Pandemi Covid-19 Di SD Inklusif. Elementary Islamic Teacher Journal, 8(2), 359-376. Google Scholar

Lisinus, Rafael, \& Sembiring, Pastiria. (2020). Pembinaan Anak Berkebutuhan Khusus (Sebuah Perspektif Bimbingan Dan Konseling). Medan: Yayasan Kita Menulis. Google Scholar

Minsih, Minsih, Nandang, Jatin Sri, \& Kurniawan, Wahyu. (2021). Problematika Pembelajaran Online Bagi Anak Berkebutuhan Khusus Di Sekolah Dasar Masa Pandemi Covid-19. Jurnal Basicedu, 5(3), 1252-1258. Google Scholar

Pakpahan, Roida, \& Fitriani, Yuni. (2020). Analisa Pemanfaatan Teknologi Informasi Dalam Pembelajaran Jarak Jauh Di Tengah Pandemi Virus Corona Covid-19. Journal Of Information System, Applied, Management, Accounting And Research, 4(2), 30-36. Google Scholar

Pradipta, Rizqi Fajar, Purnamawati, Frimha, Efendi, Mohammad, Dewantoro, Dimas Arif, Huda, Abdul, \& Jauhari, Muhammad Nurrohman. (2020). The Role Of The Resource Center In The Implementation Of Inclusion Education In Basic, Medium, And Higher Education Institutions: A Grounded Theory Approach. 1st International Conference On Information Technology And Education (Icite 2020), 490-496. Atlantis Press. Google Scholar 
Anissa Rizky Andriany, Ajheng Mulamukti Asih Pratiwi, Mahesti Pertiwi

Smith, D. D., \& Tyler, N. C. (2010). Introduction To Special Education (7th Edition) (7th Ed.). Upper Saddle River, Nj: Merrill. Google Scholar

Sukmadinata, Nana Syaodih. (2006). Metode Penelitian Tindakan. Bandung: Rosda Karya. Google Scholar

Syafarana, Ilona Aulia Nur, \& Chairani, Assyifa. (2020). Pelaksanaan Pembelajaran Anak Berkebutuhan Khusus Pada Masa Pandemi Covid-19 Di Sekolah Inklusif Sdn 12 Gedong. Jurnal Ortopedagogia, 6(2), 125-129. Google Scholar

Syarifudin, Albitar Septian. (2020). Impelementasi Pembelajaran Daring Untuk Meningkatkan Mutu Pendidikan Sebagai Dampak Diterapkannya Social Distancing. Jurnal Pendidikan Bahasa Dan Sastra Indonesia Metalingua, 5(1), 31-34. Https://Doi.Org/10.21107/Metalingua.V5i1.7072 Google Scholar

Takdir Ilahi, Mohammad. (2013). Pendidikan Inklusif Konsep Dan Aplikasi. Ar-Ruzz Media, Yogyakarta. Google Scholar

Taylor, R. L., Smiley, L., \& Richards, S. B. (2009). Exceptional Students. New York: Mc. Graw-Hill. Google Scholar

Yuliani, Meda, Simarmata, Janner, Susanti, Siti Saodah, Mahawati, Eni, Sudra, Rano Indradi, Dwiyanto, Heri, Irawan, Edi, Ardiana, Dewa Putu Yudhi, Muttaqin, Muttaqin, \& Yuniwati, Ika. (2020). Pembelajaran Daring Untuk Pendidikan: Teori Dan Penerapan. Medan: Yayasan Kita Menulis. Google Scholar

\section{Copyright holder:}

Anissa Rizky Andriany, Ajheng Mulamukti Asih Pratiwi, Mahesti Pertiwi (2021)

First publication right:

Syntax Literate: Jurnal Ilmiah Indonesia

This article is licensed under: 